\title{
SOCIAL-DEMOGRAPHIC FACTORS FOR DEVELOPMENT OF AGRICULTURAL TERRITORIES OF POLAND AND UKRAINE
}

\author{
Tsvihun Inna, $\mathrm{PhD}^{1}$ \\ Faculty of Economics, State Agrarian and Engineering University in Podilya
}

\begin{abstract}
Rural areas are an important component of the national economy and perform the following functions: efficient and competitive production; rational saving and protection of natural resources; assistance to rural population expanded reproduction; insurance of employment, proper level and quality of life as well as the revival of historical and the formation of new cultural traditions. The aim of the study is to assess the sociodemographic development of rural areas of the Ukraine and Poland and to identify common and distinctive features of their development. In order to assess the level of rural area development, the following indicators were used: rural population size and structure, fertility, mortality and expected life expectancy of the rural population. The aim of the study is to assess trends in the development of demographic processes and to develop proposals for the sustainable development of Ukrainian rural areas, taking into account the experience of Poland.
\end{abstract}

Keywords: rural areas, depopulation, birth rate, mortality, population structure, aging JEL codes: Q01, J11, J131

\section{INTRODUCTION}

Rural areas are an important socio-economic system with significant human, natural and productive resources, which is why their development determines food security and the economic well-being of any country. The development of rural areas requires an integrated approach to addressing all the problems of the rural region - economic, social, environmental and demographic. Besides, they are all interconnected and are formed depending on the national economy of the country and its history.

A reduction in the population and marginalisation of rural areas is widespread across Europe. All rural areas are suffering from depopulation, and this can undoubtedly be considered the most serious threat to the local economy, not only because this limits opportunities for development, causes important environmental problems and complicates the provision of public services, but also because it may jeopardize the existence of small villages and towns as human settlements (Pinilla, Ayuda and Sáez, 2008). An estimation of the development of demographic processes in rural areas of the Ukraine and Poland, based on a historical heritage assessment and socioeconomic development in modern conditions, will reveal the common features and trends of the rural population.

\footnotetext{
${ }^{1}$ Corresponding author: Shevchenko 13, 32300 Kamyanets-Podilskyi, Khmelnytsky region, Ukraine, ia_tsvigyn@ukr.net, +38(097) 5664641
} 


\section{THEORETICAL BACKGROUND}

In research literature, depopulation is used as a main indicator. However, although this indicator is useful for demographic trends, depopulation is rather a symptom than a cause of population decline, which is a result of a complex 'closed circle' of interconnected economic and social factors that highlights the acute problems of regional development and governance (ESPON, 2017). In addition, in different countries, this term is used differently. In Poland, this is a process of population loss and, in the Ukraine, this term characterizes a decrease in population due to low birth rates, surplus deaths and a negative balance of migration (Rink, Haase and Bernt, 2009). Although most scientists define the depopulation process as a negative phenomenon, there are no generally accepted goals or principles regarding the desirable limit of demographic change in the countryside: the goals vary between 'reduction', 'stopping' and 'returning' the depopulation of rural areas (Karcagi-Kovats and Katona-Kovacs, 2012).

Demographic development is a process of preserving population size as a result of historical progress. When this measure is fundamentally violated due to a decrease in population and a decrease in its quality, there is a demographic crisis, during which demographic development is slowed down; there is "demographic stagnation" that can eventually become a demographic catastrophe. The demographic catastrophe manifests itself in the transformation of the country or its individual regions into areas of demographic disaster (demographic distress), which manifests itself in a massive population outflow, in part or in total depopulation of territories (Steshenko, 2013). In the Ukraine, such areas of demographic disaster are primarily rural areas.

Depopulation occurs directly through the balance of two main phenomena: fertility, which is the result of birth and death number ratios and pure migration. There are many factors influencing the intensity of these phenomena from matters of religion, culture, traditions, systems of values, issues of economic and cultural life to the perception of the surrounding reality. These factors determine the number of children and the choice of place of residence, as well as living and working conditions and health systems that affect the length of our lives (Rakowska, 2011).

According to (Brown, 2013), demographic challenges in Europe include three components: a decline in population growth, driven mainly by positive immigration, aging and urbanization. At the same time (Skryzhevska and Karácsonyi, 2012), the demographic crisis is characterized by depopulation, aging and a decrease in expected life expectancy, as well as low fertility and marriage, deteriorating health and degrading education quality of rural residents, accompanied by a displacement of young and physically active people of the population.

\section{MATERIALS AND METHODS}

The article on the study of rural areas was designed on the basis of administrative criteria - the population included in the rural population living in villages and urban-type settlements in the Ukraine and rural areas in urban-rural communities are defined as rural areas. Data published by the Central Statistical Office of Poland and the State Statistics Service of the Ukraine were used to realize the intended research objectives, in the retrospective part, for the period 1959-2016. In the study, according to source material, the rural population number and its population structure divided into 5 -year age groups was applied. The analysis of the structure of the age groups of the rural population of both countries in 1959 and 2016 was carried out using estimation of similarities. For the estimation of the demographic situation in the countryside general coefficients of mortality and fertility were used as demographic factors. The depopulation ratio shows the ratio of the deceased population to the born. The dependence coefficient is an indicator that shows the ratio of dependents from zero to 14 and over 65 years of age.

\section{RESULTS AND DISCUSSION}

The demographic situation is a manifestation of population reproduction at a specific time and place, which is formed under the influence of various factors that are related to territorial features, the level of national economy and globalization development. Today, in Europe, there is a decrease in the size of the 
rural population. Depopulation tendencies are also characteristic of the Ukraine and Poland (Fig. 1). In 2017, the rural population counted 13.1 million people in the Ukraine, and 15.3 million people in Poland. In 1959, it was 22.7 and 15.5 million, respectively. Also, the share of rural population in the total number changed considerably: in Poland from 53 to $40 \%$, and in the Ukraine from 54 to $31 \%$, respectively. In general, for the period 1959-2017, the rural population of the Ukraine decreased by 9.7 million people and, in 2017 , it constituted only $57 \%$ of the level in 1959 . In Poland, during this period, the population decreased slightly - 198 thousand people, although it should be noted that, in the years 1977-2009, the population of rural areas was smaller and ranged from 14.5 to 15 million people. The sharp decline in the rural population of the Ukraine in 2014 was down to military actions in the country and failure to take into account the part of the population of occupied territories.

One of the factors of population formation and its reproduction is the sex-age structure of the population, which, on the one hand, forms the type of reproduction of the population and, on the other hand, is the result of demographic processes. The Polish countryside is constantly undergoing a process of change. It not only concerns economic phenomena, but also socio-demographic ones. An important role in the formation of demographic processes was played by the systemic transformation that took place in Poland in the 1990s. This led to significant changes in the structure of the rural population (Gierańczyk and Gierańczyk, 2012). The same situation applies to the Ukraine, a significant loss of the rural population considerably deteriorated its structure (Fig. 2). The structure of the rural population of both countries shows narrowed reproduction, since the basis of the pyramid is much narrower. The population of Poland is higher than in the Ukraine, especially in the age range of 15-59 years, while, in the Ukraine, there is a much larger number of women aged 70 and over. The age of balancing, that is, when men and women amount to the same number and then the male population decreases, is much higher in Poland and is 65, whereas in the Ukraine it is 40, which indicates a high mortality rate of men at a young age, which causes a significant number of single women. The analysis of the gender-age pyramid also suggests a significant prevalence of a population of working age (15-50), which is $52 \%$ in Poland, and $48 \%$ in the Ukraine. This testifies to a 'demographic dividend' existence, since

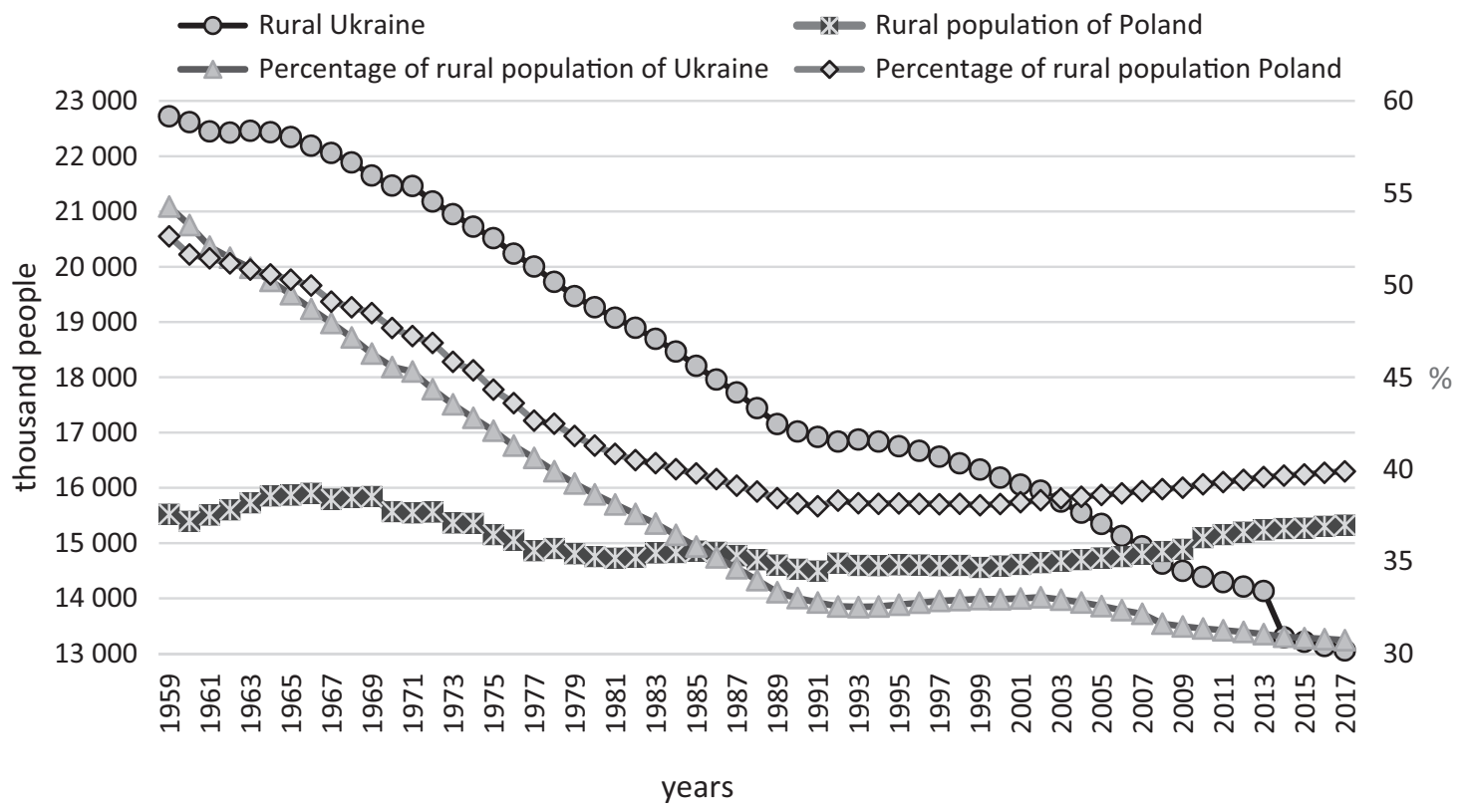

Figure 1. The number and percentage of the rural population of Ukraine and Poland Source: GUS (2017), data of State Statistics Service of the Ukraine. 


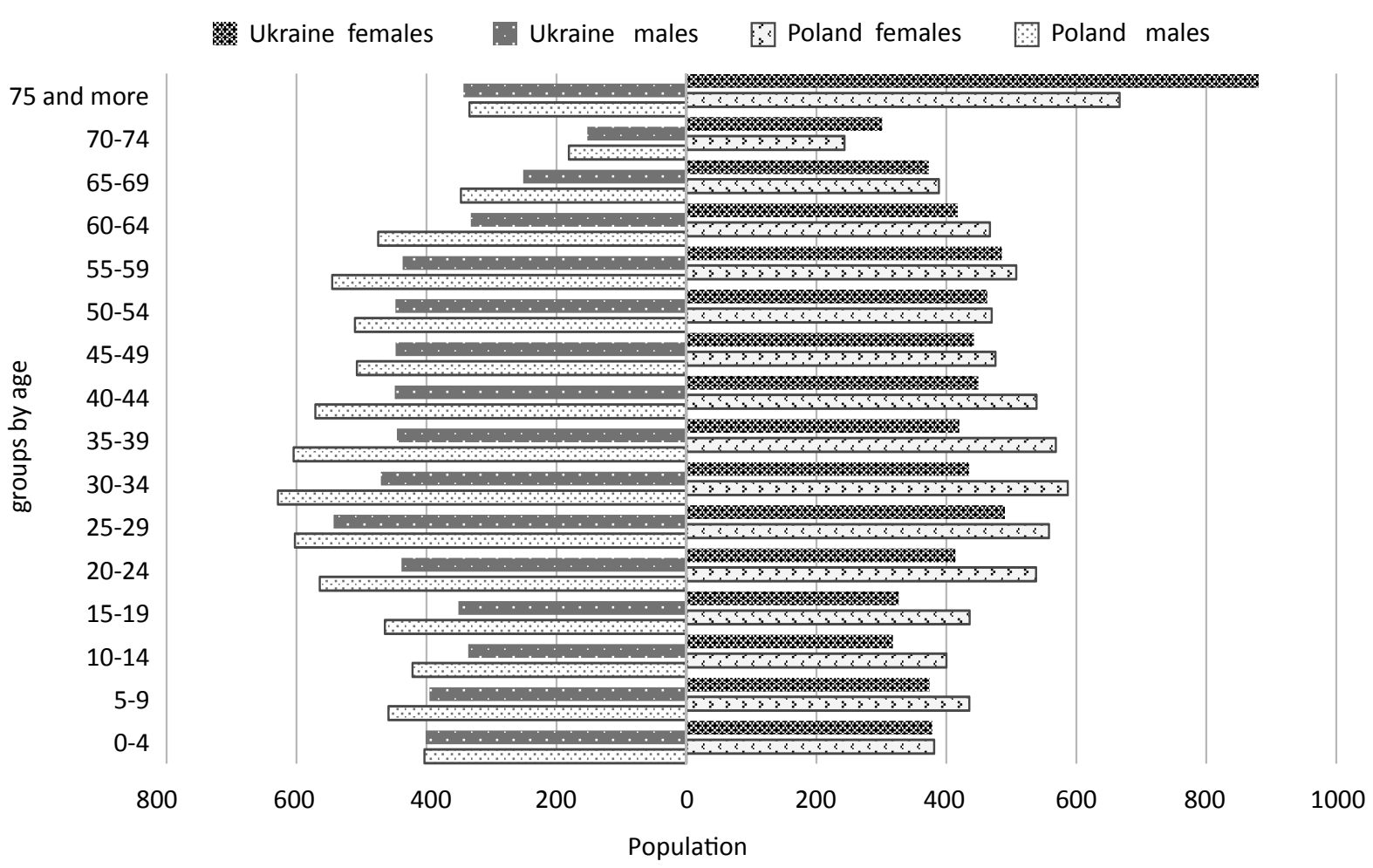

Figure 2. Sex and age structure of rural population of Ukraine and Poland in 2006

Source: GUS (2017), data of State Statistics Service of the Ukraine.

there are many able-bodied people. It is worth noting that in 30-40 years the situation will change and significant aging of the population will take place.

Aging of the population is one of the most important demographic and social trends of the $21 \mathrm{st}$ century and affects almost all countries of the world. Increasing life expectancy is truly a great achievement of development and healthcare. However, it also creates obvious challenges. Older people are going to represent a proportionately larger proportion of the total population, presenting social, economic and cultural problems for individuals, families, social welfare systems and society.

Poland, like most OECD countries, is experiencing aging through a combination of high life expectancy, birth rates and emigration (OECD, 2018). The ratio of dependency or replacement of generations, which shows a balance between children and pensioners, is steadily decreasing. If, in 1959, it was 2.2 for the rural population of Poland, and 1.3 for the Ukraine, and in 2016, these figures were 1.15 and 0.96 respectively, this testifies that in the villages of the Ukraine there is no substitution of generations due to low birth rates and a high aging of the population. In other words, the size of each new generation is smaller than the previous one. The proportion of children and adolescents is steadily declining, which causes structural changes in favour of a proportion of older people.

In 2017, the share of rural population over the age of 65 in Poland was $14.7 \%$, while in the Ukraine it was $17.4 \%$. On a UN scale, if the proportion of people over 65 is over $7 \%$, it is considered old. It is worth noting that the demographic aging of the population is an objective, historical process. Its consequences are irreversible and the only thing that can and must be done is to realize its inevitability and historical nature and take this into account in public practice, in particular in developing demographic policy measures.

In demography, aging from the bottom arises due to a significant increase in life expectancy, and aging from above - due to a significant decline in fertility. While analysing the birth and death rates between 
Proceedings of the 2018 International Scientific Conference 'Economic Sciences for Agribusiness and Rural Economy' No 2, Warsaw, 7-8 June 2018, pp. 294-299

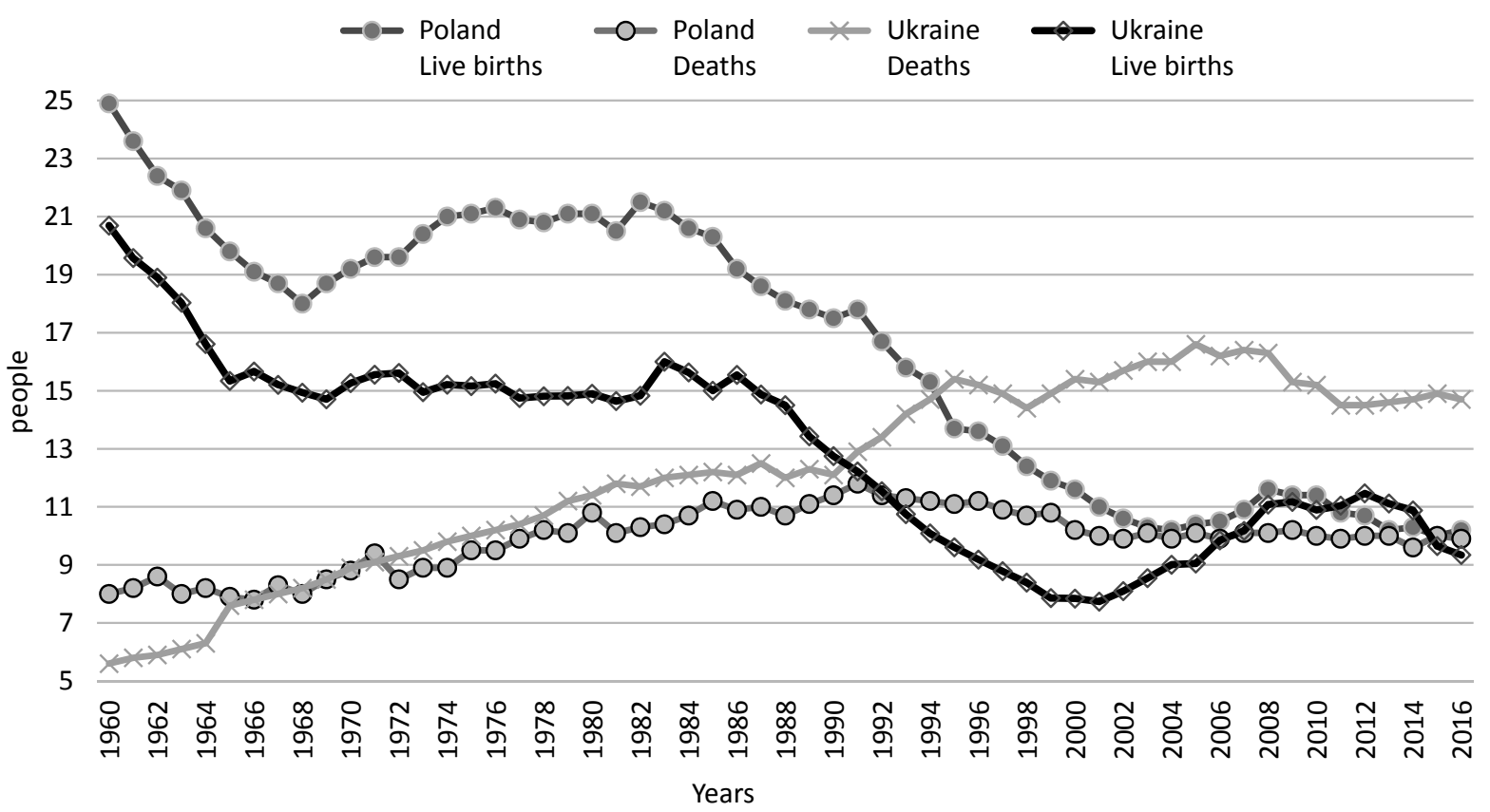

Figure 3. Coefficients of fertility and mortality of rural population in Ukraine and Poland Source: GUS (2017), data of State Statistics Service of the Ukraine.

1960-2016 (Fig. 3), it was found that both countries experienced an increase in mortality and fertility rates however, in the Ukraine, the mortality rate is much higher: the mortality rate increased 2.6 times in the Ukraine and 1.25 times in Poland. As a result, since 1991, a natural loss in the Ukrainian population, which in the year 2016, amounted to $5.4 \%$, has taken place. At that time, Poland witnessed a natural increase, and, although it is quite small $0.3 \%$, the population did not decrease due to natural losses. The causes of high mortality in the Ukraine are related to the structure of the population, namely, the significant aging of the population.

Among demographic indicators, there is one more, which is used for the integral assessment of population health - average life expectancy. This indicator is especially influenced by an increase in mortality among children, youth and people of working age. Therefore, it has a more practical significance than the overall mortality rate, which is significantly influenced by the high frequency and specific gravity of the mortality of the working age population (Fig. 4).

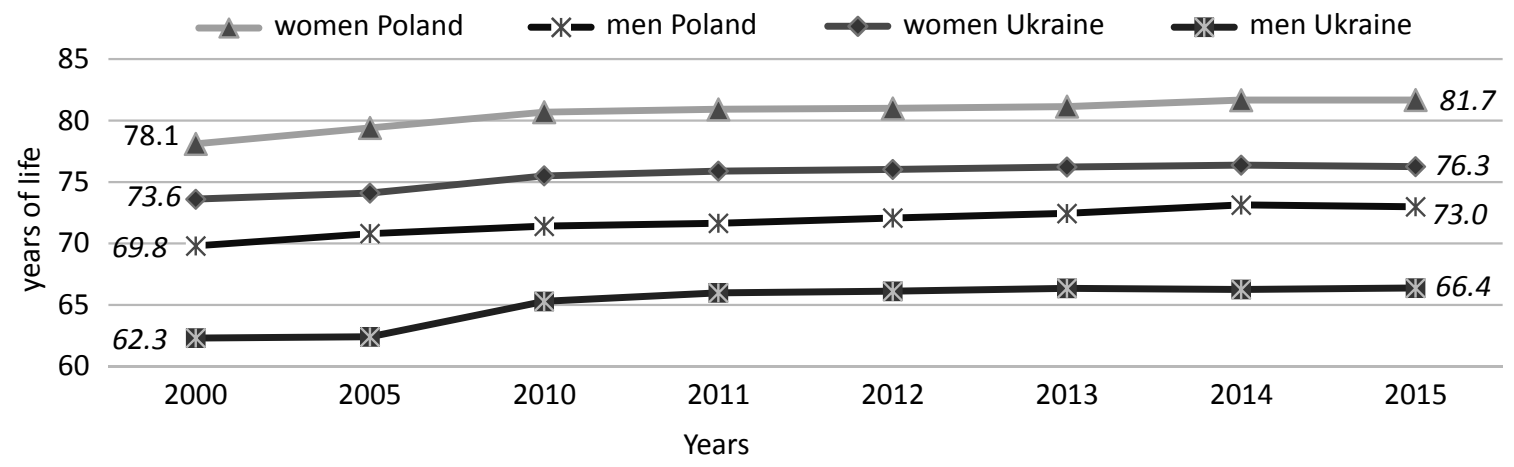

Figure 4. Average life expectancy at birth in Ukraine and Poland Source: GUS (2017), data of State Statistics Service of the Ukraine. 
Figure 4 shows the highest life expectancy at birth, both for men and women in Poland. Women in Poland are expected to live 5.5 years longer, while men will be 6.5 years older. It is worth noting that, in both countries, there is a significant gap between the expected life expectancy of women and men, that is, the Incas live longer, in Poland by 8.7 years, and in the Ukraine - by 9.7 years. WHO believes that life expectancy is influenced by $50 \%$ of life span, namely smoking, alcohol, malnutrition, which explains such a significant gap.

\section{CONCLUSIONS}

The current demographic, social and economic situation in the countryside indicates that depopulation will continue as a result of further migration and high mortality. This can lead to a reduction in rural settlements and an increasingly aging population, and therefore more dependent. The Ukraine needs to focus on increasing the economic attributes of the countryside. Diversification of agriculture for entrepreneurs, both at agricultural and non-agricultural enterprises, for the creation and preservation of jobs outside agricultural activity, can help reduce rural departures and improve living conditions in rural areas. The development of a rural infrastructure (roads, sewage), which remains limited in some rural areas, and eco-tourism will create new jobs.

That is, creating conditions of work and life of countryside inhabitants in accordance with civilization standards, establishing conditions for sustainable development in rural areas, protecting natural resources and rural cultural heritage and increasing the standard of living of the population will allow depopulation trends to be suspended and facilitate reorganization.

\section{REFERENCES}

1. Brown, D. (2013). Rural Population Change Matters, But Demography Is Not Destiny. Przegląd Socjologiczny, 52, pp. 135-149.

2. ESPON (2017). Policy Brief on Shrinking Rural Regions. Retrieved from: https://www.espon.eu/ruralshrinking.

3. Gierańczyk, W., Gierańczyk, W. (2012). Zmiany demograficzne na obszarach wiejskich w Polsce w latach 2010-2035 [Demographic changes in rural areas in Poland in 2010-2035]. Roczniki Naukowe SERiA, 14 (3), pp. $80-85$.

4. GUS (2017). Rocznik Demograficzny 2017 [Demographic Yearbook of Poland]. Dział Wydawnictw Statystycznych GUS, Warszawa.

5. Karcagi-Kovats, A., Katona-Kovacs, J. (2012). Factors of population decline in rural areas and answers given in EU member states' strategies. Studies in Agricultural Economics, 114 (1), pp. 49-56.

6. OECD (2018). OECD Rural Policy Reviews: Poland 2018. OECD Publishing, Paris. http://dx.doi.org/10.17 87/9789264289925-en

7. Pinilla, V., Ayuda, M., Sáez, L. (2008). Rural Depopulation and the Migration Turnaround In Mediterranean Western Europe: A Case Study of Aragon. Journal of Rural and Community Development, 3, pp. 1-22.

8. Rakowska, J. (2011). Zmiany demograficzne na obszarach wiejskich Polski [Demographic changes in rural areas of Poland]. Wieś Jutra, 160/161, pp. 7-10.

9. Rink, D., Haase, A., Bernt, M. (2009). Workpackage 1. Specification of working model. Leipzig, Helmholtz Centre for Environmental Research.

10. Skryzhevska, Y., Karácsonyi, D. (2012). Rural population in Ukraine: assessing reality, looking for revitalization. Hungarian Geographical Bulletin, 61 (1), pp. 49-78.

11. Steshenko, V. (2013). Zmist poniat 'demohrafichnyi rozvytok' i 'liudskyi rozvytok': totozhnosti ta vidminnosti. Demohrafiia ta Socialna Ekonomika, 1 (19), pp. 5-16. 